\title{
The New Natural Distribution Area of Aspen (Populus tremula L.) Marginal Populations in Pasinler in the Erzurum Province, Turkey, and its Stand Characteristics
}

\author{
Halil Barış Özel ${ }^{1}$, Sezgin Ayan ${ }^{2 *}$, Serdar Erpay ${ }^{1}$, Bojan Simovski ${ }^{3}$
}

(1) University of Bartn, Faculty of Forestry, TR-74100 Bartn, Turkey; (2) Kastamonu University, Faculty of Forestry, TR-37100 Kuzeykent, Kastamonu, Turkey; (3) Ss. Cyril and Methodius University in Skopje, Faculty of Forestry, Aleksandar Makedonski bb, MK-1000 Skopje, Republic of Macedonia

* Correspondence: e-mail: sezginayan@gmail.com
Citation: ÖZEL HB, AYAN S, ERPAY S, SIMOVSKI B 2018 The New Natural Distribution Area of Aspen (Populus tremula L.) Marginal Populations in Pasinler in the Erzurum Province, Turkey, and its Stand Characteristics. South-east Eur for 9 (2): 131-139. DOI: https://doi. org/10.15177/seefor.18-15

Received: 18 Oct 2018; Revised: 2 Dec 2018, 6 Dec 2018; Accepted: 9 Dec 2018; Published online: 22 Dec 2018

\begin{abstract}
Background and Purpose: Genetic diversity is the basis for adaptation and survival of tree species under changing environmental conditions, representing the key issue of stability and productivity of forest ecosystems. This paper studies the marginal population characteristics and stand dynamics of aspen tree (Populus tremula L.) in natural, pure and mixed forest stands with Scots pine (Pinus sylvestris L.). These populations were observed on founding sites between Timarli Valley and Timan Plateau located in Pasinler in the Erzurum Province in Turkey.

Materials and Methods: Three replicated sample sites were established according to a randomised block design with a spacing of approximately $200 \mathrm{~m}$ in altitude starting from $1,890 \mathrm{~m}$, which is the natural distribution area of $P$. tremula, up to 2,460 m, above which this species can no longer thrive. Timarlı Valley, Pasinler Erzurum Province, which is the area of research, is located enroute to Timan Plateau, where Scots pines form the alpine tree line ranging up to $2,680 \mathrm{~m}$ a.s.l.

Results: In this context, aspen trees in this region are the second closest tree species to the tree line after Scots pine, which are found in the subalpine and war zones. In addition, as a result of this study, it has been found out that this species, notwithstanding its natural area of occupancy across Turkey, could thrive up to $2,460 \mathrm{~m}$ in altitude and extent of occurrence.

Conclusions: A new marginal natural population related to aspen has been found in Pasinler in the Erzurum Province, Turkey, which at the same time indicates that the timberline value in the vertical natural distribution of these species should be updated. Aspen trees, which as pioneer trees play a vital role in the rebuilding or restoring of the ecological balance in forests that over time become degraded because of excessive cutting of trees and erroneous silvicultural interventions should be used in the reclamation of broadleaved and mixed forests in a planned manner. Genetic resources that represent marginal and peripheral populations, both within and outside the natural distribution area, should be established and protected.
\end{abstract}

Keywords: Aspen, Scots pine, stand characteristics, natural distribution, elevation, marginal population

\section{INTRODUCTION}

According to the latest statistics, forest area in Turkey covers up to 22.7 million ha [1]. It has been observed that many broadleaved and coniferous forest tree species in a forest area of this size have formed a wide geographical variation according to their natural distribution inclinations in different ecological conditions [2, 3]. The most prominent species in this wide geographical variation is aspen (Populus tremula $\mathrm{L}$.). This tree species has a wide distribution area across Europe, West Asia and North Africa. P. tremula trees have cylindrical trunks, dense branches and wide conical 
crown, and they can grow up to 25 metres in height [4, 5]. Being one of the many pioneer species, aspen trees demonstrate fast growth followed up by strong root suckers. Although there are not many studies about aspen trees in Turkey, this species is reported to have a natural range all around Turkey where it forms mixed forests with broadleaved and coniferous species such as Scots pine, larch and fir at 2,000-2,350 metres a.s.l., excluding the steppes of Southeastern and Central Anatolia [4, 6]. Previous research on $P$. tremula also indicated that there are pure stands of this species across regions of Çanakkale-Yenice, Sarıkamış, Göle, Lake Van, Kayseri-Erciyes Mountain, Kahramanmaraş and Isparta. [7-9].

The limited number of studies conducted in Turkey, literature on forest trees in Europe, and especially EUFORGEN programme concerning the natural distribution area of these species did not record any information regarding aspen trees forming pure or mixed stands with Scots pine between 1,890-2,460 metres in the area of Timarlı Valley and Timan Plateau located in Pasinler in the Erzurum Province (Figure 1). In this research, the aim was to determine the stand characteristics of the marginal populations of pure and mixed forest stands with Scots pine of aspen trees found in Timarlı Valley and Timan Plateau. Additionally, a new natural distribution area of the aspen tree has been discovered.

\section{MATERIALS AND METHODS}

\section{Material}

The research was carried out in Timarlı Valley and Timan Plateau, on an altitude ranging from 1,890 to 2,460 $\mathrm{m}$ a.s.l. in Pasinler in the Erzurum Province. Coordinates of the investigation area are as follows: $40^{\circ} 04^{\prime} 25^{\prime \prime}-41^{\circ} 43^{\prime} 45^{\prime \prime}$ and $40^{\circ} 08^{\prime} 24^{\prime \prime}-41^{\circ} 44^{\prime} 45^{\prime \prime}$ (Figure 2).

The long-term climate data of 50 years of the research site have been analysed. As a result of the analyses, it was found that the lowest temperature at the research site was $-23.6^{\circ} \mathrm{C}$ in January and the highest temperature $27.9^{\circ} \mathrm{C}$ in July. In addition, precipitation at the research site was measured as $69 \mathrm{~mm}$ in August (lowest) and $658 \mathrm{~mm}$ in May (highest). Vegetation period of the research site is five months (May-September) [10]. When the soil structure of the study area was examined, it was determined that the geological structure was formed mainly of metamorphic rocks from the Triassic-Cenomanian periods with varying age ranges. The stoniness rate of the surface of the research site is rather high with $73.2 \%$, and the soil is of medium depth. Limestone is very common in this area and the rate of organic matter in the soil is rather low. Furthermore, the structure of the area is detrital and the soil texture is clayeysandy-loamy. Both the soil consolidation and surface flow rating are higher on topsoil in this area [11].

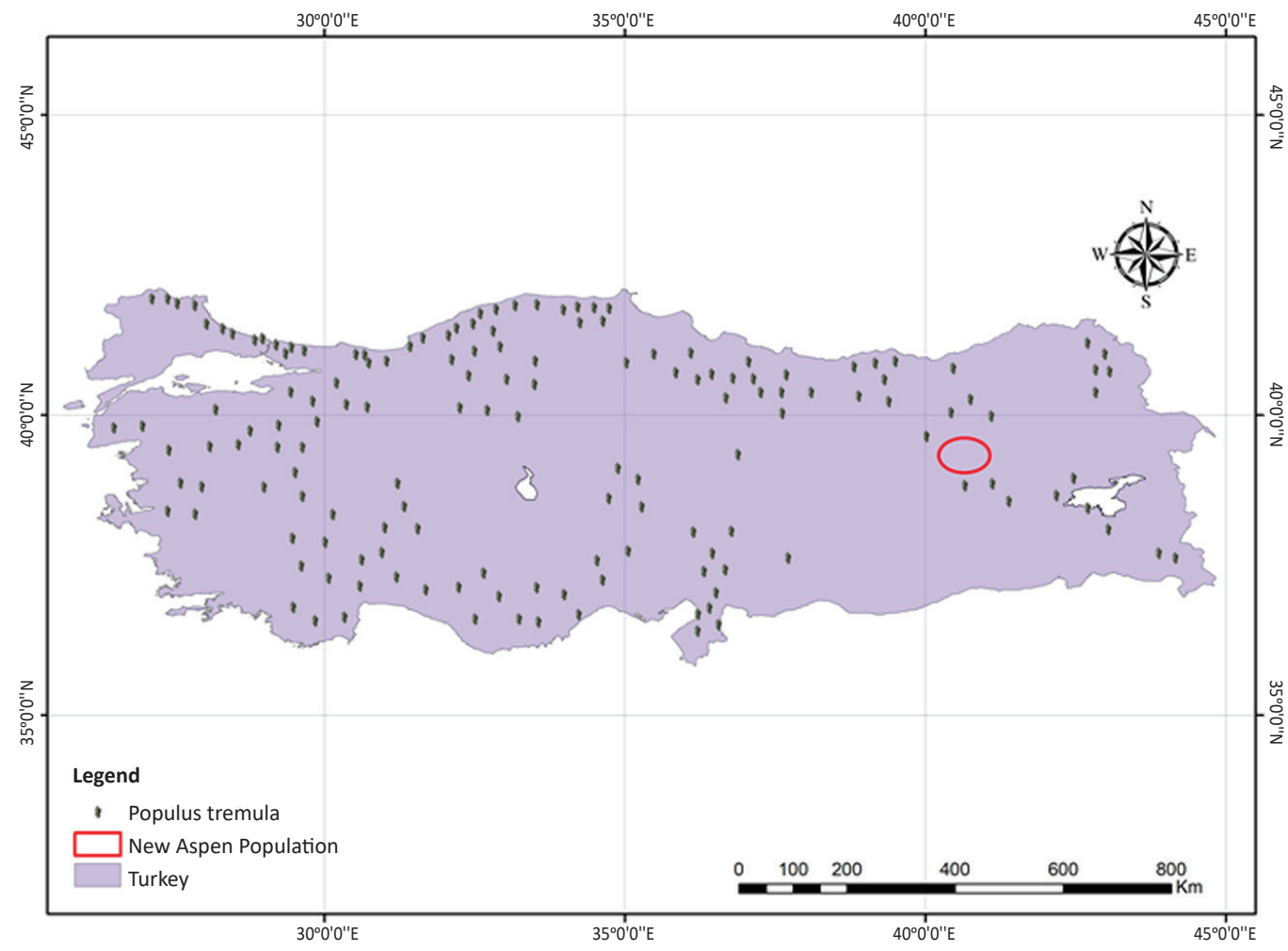

FIGURE 1. Natural distribution area (extent of occurrence, marked with red ellipse) of Populus tremula in Turkey [4]. 


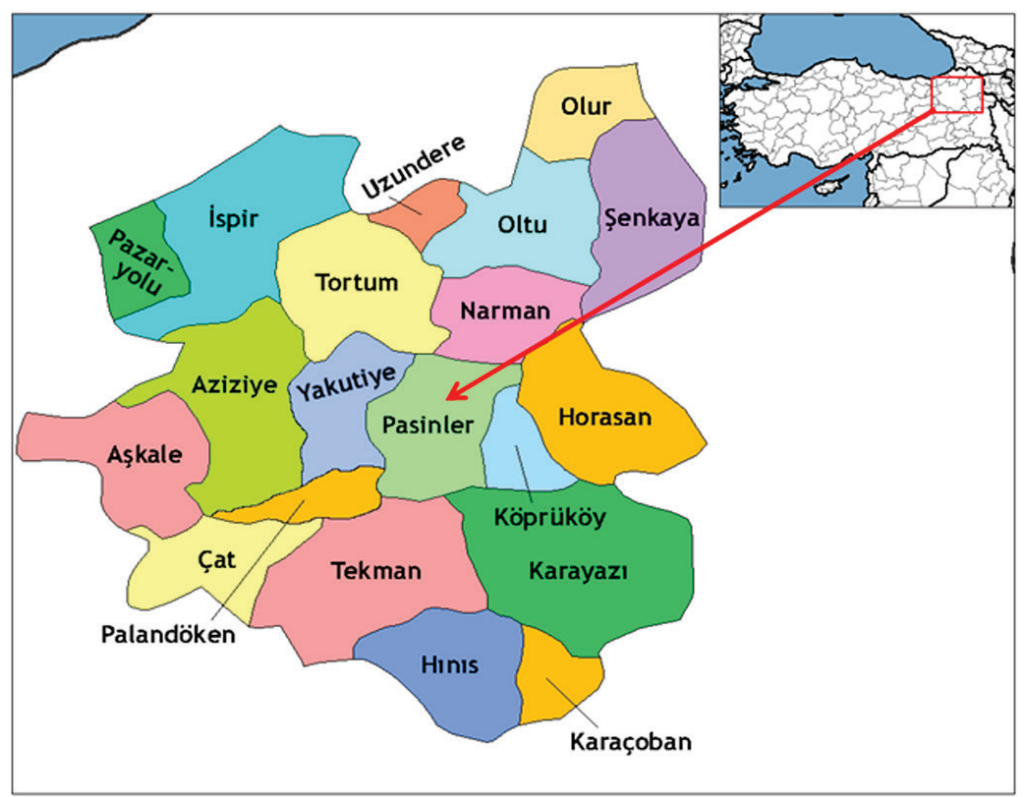

FIGURE 2. Investigation area.

\section{Method}

The structural characteristics of both pure and mixed aspen - Scots pine stands have been investigated on four different altitudes, starting from Timarli Valley at 1,890 metres and ending with Timan Plateau at 2,460 metres in Pasinler in the Erzurum Province. In this context, three replicated sample sites, which consisted of pure $P$. tremula and mixed stands with Scots pine, were established according to randomised block design at $200 \mathrm{~m}$ intervals with $25 \times 40 \mathrm{~m}$ spacing. The locations of the trees sample sites were determined with GPS devices and stand profile was prepared using Vector Packet Program. On the other hand, the physiographic conditions such as elevation, slope and aspect of stands on the sample sites were also determined with GPS devices. Furthermore, both aspen and Scots pine trees on the sample sites were measured with digital tree callipers and metres. Canopy cover value in the sample sites was measured with a spherical densitometer.
The frequency of stands, site index and volume values were determined with the help of volume tables for aspen and Scots pine, presented by Bayburtlu [12] and Pehlivan [13] respectively. The increment core of one of the trees in the middle of the sample sites was removed just above the ground level to estimate the average age of the species (tree rings). Three replications in each altitude level were applied to determine tree age.

\section{RESULTS AND DISCUSSION}

During the research conducted in the investigation area, detailed data were collected from the sites. Table 1 presents the collected data of the four established sample sites with specific characteristics of both pure aspen and mixed forest stands with Scots pine.

TABLE 1. The characteristics of pure aspen and mixed forest stands with Scots pine in Pasinler in the Erzurum Province.

\begin{tabular}{|c|c|c|c|c|c|c|c|c|c|c|}
\hline Sample stand & $\begin{array}{l}\text { Altitude } \\
\text { (m) }\end{array}$ & Aspect & $\begin{array}{c}\text { Slope } \\
(\%)\end{array}$ & Canopy & $\begin{array}{c}\text { Stand } \\
\text { density }\end{array}$ & $\begin{array}{c}\text { Site } \\
\text { index }\end{array}$ & $\begin{array}{c}\text { Average } \\
\text { tree height } \\
\text { (m) }\end{array}$ & $\begin{array}{c}\text { Tree number } \\
\left(\text { trees } \cdot \mathrm{ha}^{-1}\right)\end{array}$ & $\begin{array}{l}\text { Diameter } \\
\quad(\mathrm{cm})\end{array}$ & $\begin{array}{l}\text { Mean volume } \\
\qquad\left(\mathrm{m}^{3} \cdot \mathrm{ha}^{-1}\right)\end{array}$ \\
\hline $\begin{array}{l}1^{\text {st }}: \text { Pure } \\
\text { Aspen }\end{array}$ & 1,890 & NW & 35.6 & 0.6 & 0.5 & III & 6.2 & 4,123 & 14.8 & $23.9-90.7$ \\
\hline $2^{\text {nd }}$ : Pure Aspen & 2,100 & $\mathrm{NE}$ & 47.2 & 0.7 & 0.5 & III & 4.7 & 3,080 & 12.8 & $21.8-43.2$ \\
\hline $\begin{array}{l}3^{\text {rd: }} \text { Mixed } \\
\text { Aspen \& } \\
\text { Scots pine }\end{array}$ & 2,270 & $\mathrm{~N}$ & 45.7 & 0.5 & 0.3 & III & $\begin{array}{l}4.2 \\
5.6\end{array}$ & 2,976 & $\begin{array}{r}8.3 \\
11.7\end{array}$ & $\begin{array}{l}14.6-20.2 \\
21.8-49.4\end{array}$ \\
\hline $\begin{array}{l}4^{\text {th }} \text { : Mixed } \\
\text { Aspen \& Scots } \\
\text { pine }\end{array}$ & 2,460 & $\mathrm{~N}$ & 41.6 & 0.8 & 0.7 & III & $\begin{array}{l}4.5 \\
5.3\end{array}$ & 3,150 & $\begin{array}{l}6.7 \\
9.2\end{array}$ & $\begin{array}{l}9.2-14.3 \\
28.6-62.5\end{array}$ \\
\hline
\end{tabular}


The first sample site designated for this research consisted of pure stands of aspen trees formed at 1,890 metres (Figure 3 ). This stand was located on a middle slope position. It was a single layered stand, and the average age of even-aged aspen individuals was 23.

Mean volume of pure aspen stands with poor yield rating in a similar sample site with extreme habitat conditions located in Norway at 1,910 metre altitude was reported to be between 19.8-126.7 $\mathrm{m}^{3} \cdot \mathrm{ha}^{-1}$ [14]. According to this comparative analysis, the state of development of the pure aspen stand studied in this research area at the mentioned altitude level, notwithstanding the prevailing extreme habitat conditions of the area, could be said to be satisfactory.

The second sample site designated for this research was established at 2,100 metres, $200 \mathrm{~m}$ higher in altitude than the first sample site (Figure 4). This stand was located on a steep slope position on north-east aspect (Table 1). It was a single layered stand, and the average age of even-aged aspen individuals was 15 years.
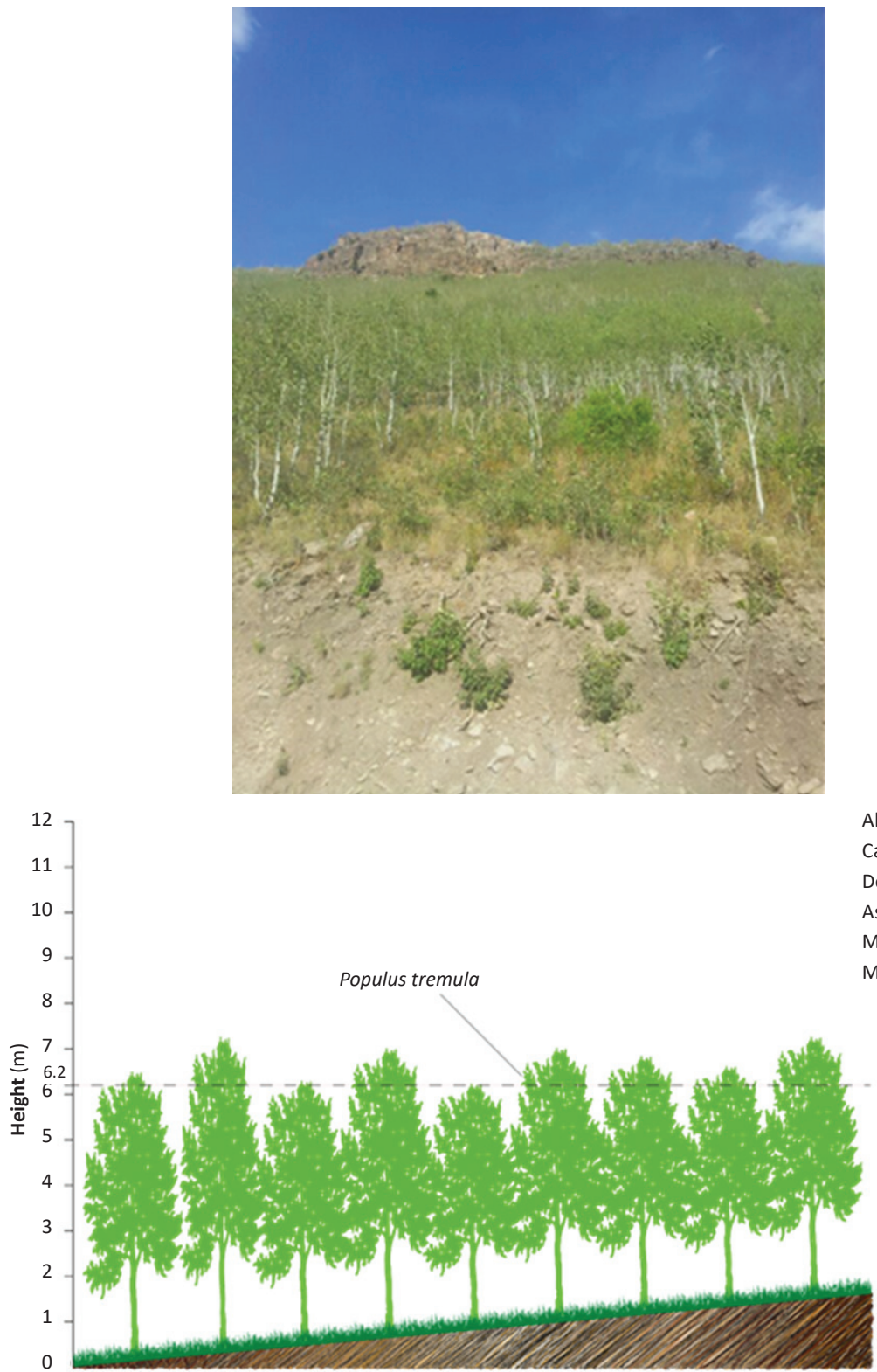

FIGURE 3. Profile of pure Populus tremula stand at the first altitude level (1,890 m.a.s.I.).
Altitude $(\mathrm{m})=1890$

Canopy $=0.6$

Density $=0.5$

Aspect $=\mathrm{NW}$

Mean Height $(\mathrm{m})=6.2$

Mean Diameter $(\mathrm{cm})=14.8$ 

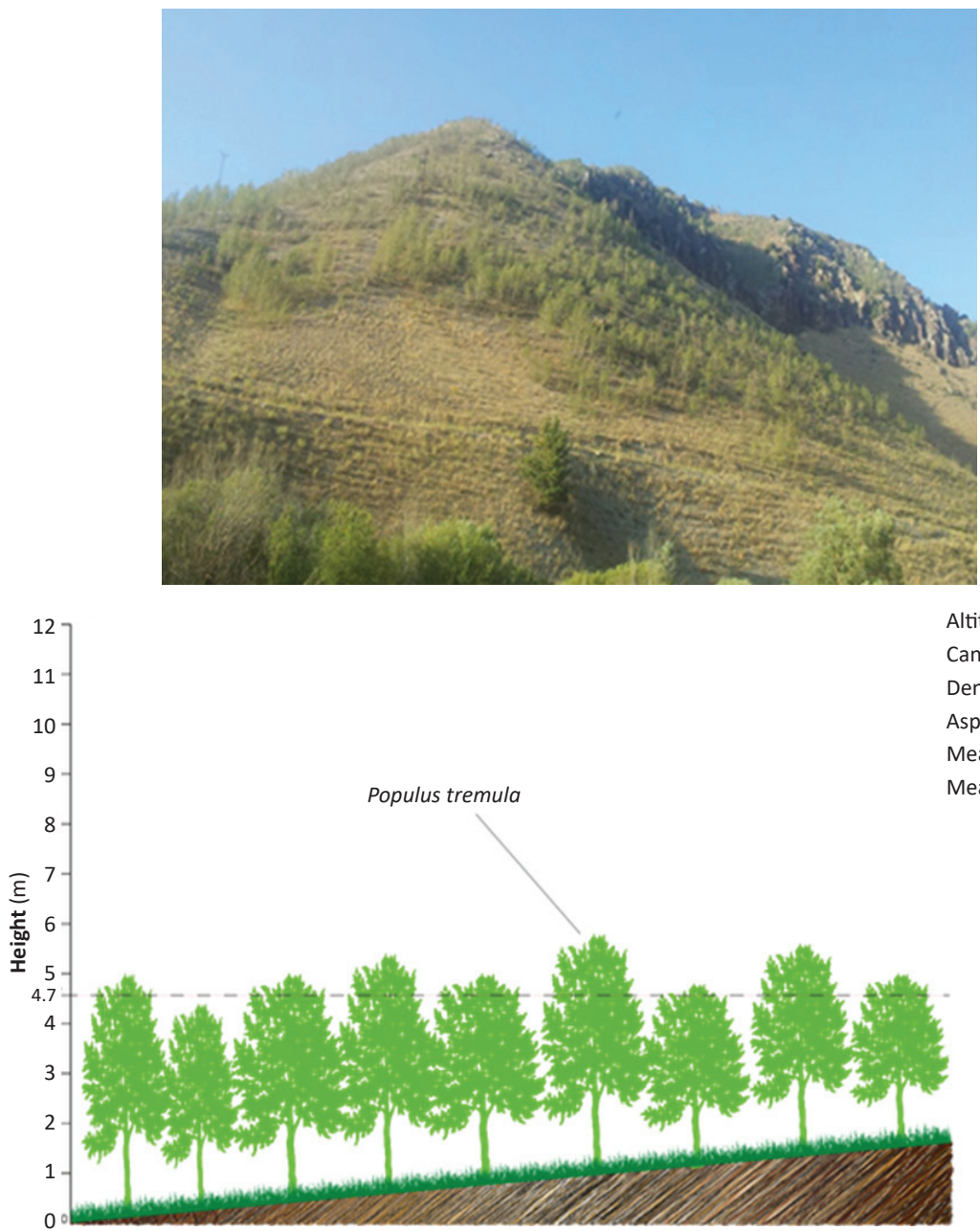

Altitude $(m)=2100$

Canopy $=0.7$

Density $=0.5$

Aspect $=\mathrm{NE}$

Mean Height $(\mathrm{m})=4.7$

Mean Diameter $(\mathrm{cm})=12.8$

FIGURE 4. Profile of a pure Populus tremula stand at the second altitude level (2,100 m.a.s.I.).

The average volume of aspen trees in a research conducted in Russia at 2,165 metres altitude was reported to be between 17.4-56.7 $\mathrm{m}^{3} \cdot \mathrm{ha}^{-1}$. According to this research, high winds in the mentioned altitude and a large portion of snowfall in the region caused the trees to split and fall on. Therefore, they had intense negative effects on the remaining aspen stand in the sample site [15]. Similar to this research, it has been found that in the current sample site, above $2,000 \mathrm{~m}$, especially at 2,100 $\mathrm{m}$, there was a significant increase in the number of fallen trees. In addition, a sudden decline in the soil depth has been observed, and the parent material has been found too close to the surface at many points. Even in these negative circumstances, the protection, resistance and vitality of the pure aspen stand was found to be very satisfactory. Even though the volume of this stand is rather low, it plays a vital role in the prevention of landslides, erosion and avalanches that might occur at 2,100 $\mathrm{m}$ a.s.l., considering the high slope of the terrain.
The next sample site was established at 2,270 $\mathrm{m}$ a.s.l. (Figure 5).

Scots pine trees form a mixed stand with aspen trees on an individual basis starting from 2,180 m. However, the altitude at which they join up with aspen trees as clusters and groups at a rate of $10 \%$ or higher is at $2,270 \mathrm{~m}$. The stand was located on a medium slope position. Average ages of the aspen and Scots pine trees were 18 and 24 years, respectively. The mean number of Scots pine in the site was 1,584 (Table 1). It was as double layered stand with Scots pine on the top, and aspen trees in the intermediate layer. The volume of aspen trees at this altitude level was measured between 14.6-20.2 $\mathrm{m}^{3} \cdot \mathrm{ha}^{-1}$. The volume of Scots pine trees at the same site was between 21.8-49.4 $\mathrm{m}^{3} \cdot \mathrm{ha}^{-1}$. This indicates that aspen trees, while being among pioneer species, have started to lose their dominance to Scots pine in the mixed stand. Moreover, a research conducted in the forests mixed with European spruce trees (Picea abies (L.) 

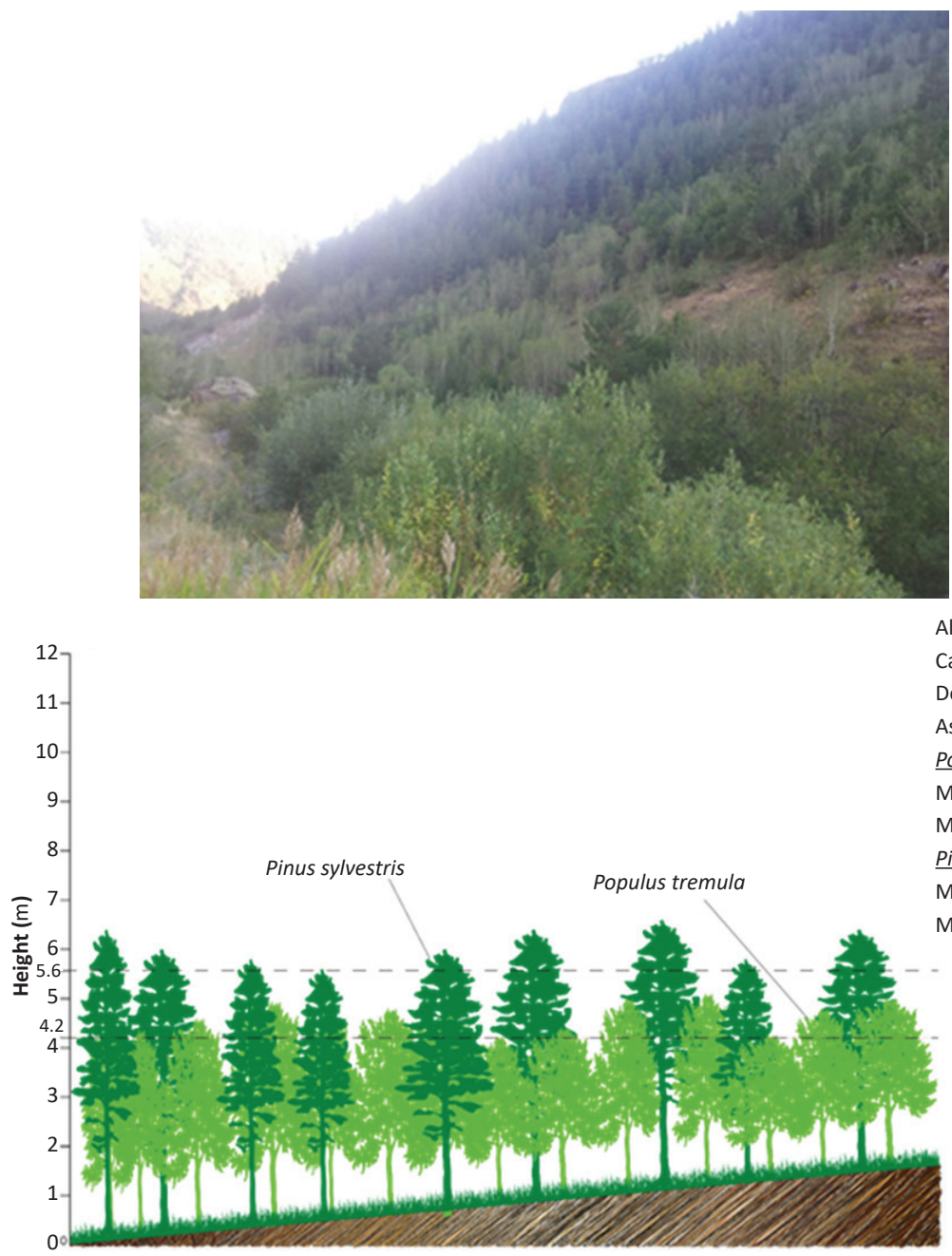

Altitude $(m)=2270$

Canopy $=0.5$

Density $=0.3$

Aspect $=\mathrm{N}$

Populus tremula

Mean Height $(\mathrm{m})=4.2$

Mean Diametar $(\mathrm{cm})=8.83$

Pinus sylvestris

Mean Height $(\mathrm{m})=5.6$

Mean Diametar $(\mathrm{cm})=11.7$

FIGURE 5. Profile of Populus tremula and Pinus sylvestris stands at third altitude level $(2,270 \mathrm{~m}$ a.s.l.)

Karst) in Lithuania has shown that the number and density of aspen trees decreased significantly at 2,300 $\mathrm{m}$ and at higher altitudes when they became part of a mixed stand with European spruce trees. The average number of aspen trees were reported to be between 2,856-3,579, lesser than that of European spruce trees. The research in question has also revealed that in regions where double-layered structures were often predominating, the European spruce trees started to gain dominance over other trees from an early age, thanks to their fast growth rate [16].

The last sample site was established on Timan Plateau at 2,460 m a.s.l. (Figure 6).

The highest and last altitude, at which a sample site was established according to $200 \mathrm{~m}$ altitude intervals determined within the context of this research, was 2,460 $\mathrm{m}$. It was located on a high slope position (Table 1). Average tree ages of aspen and Scots pine were 13 and 19 years, respectively. The mean number of aspen and Scots pine at the site was 1,016 and 2,134. It was structured as a doublelayered stand with Scots pine on top, and with aspen trees in the intermediate layer. Scots pine trees alone form the alpine tree line on Timan Plateau, at 2,680 m.

In this context, the aspen trees in this region are the second closest tree species to the tree line after Scots pines, which are found in the subalpine and war zones. Indeed, according to a number of studies concerning the silviculture of trembling aspen trees, it was reported that this species of aspen trees, thanks to their resilient nature, are able to form tree lines in their natural distribution areas or grow up to subalpine layers [17-19]. Similarly, a research carried out in Canada concerning a forest with broadleaved trees at 2,532 $\mathrm{m}$ has shown that aspen trees are able to thrive in war zones, and that they could grow up to the subalpine layer. The number of aspen trees per ha in this region was reported to 
be between 897 and 1,153. In this research, as is the case in our research as well, aspen trees were found to retreat into the intermediate layer, and their trunk and top structures began to deform [20,21]. In the light of these evaluations, a new natural distribution area of trembling aspen trees, one that has no mention in literature concerning this specific species in Turkey, has been discovered in the area between Timarlı Valley and Timan Plateau, at varying altitude levels. Stand statistics and stand profiles of pure and Scots pine mixed stands of aspen trees in this new natural distribution area were drawn.
As a result of this study, a cross-section of pure aspen and Scots pine mixed stands of aspen trees between Timarlı Valley and Timan Plateau has been made (Figure 7).

As it can be seen in Figure 7, aspen trees form pure and Scots pine mixed stands all around the sample site. In addition, when the literature on aspen trees in Turkey is analysed, it can be seen that the vertical altitude level of these species is between 2,200 (lowest) and 2,350 (highest) $[4,5,22]$. Also, as a result of this study, it has been found out that aspens, notwithstanding their natural distribution areas across Turkey, could thrive up to $2,460 \mathrm{~m}$ in altitude.
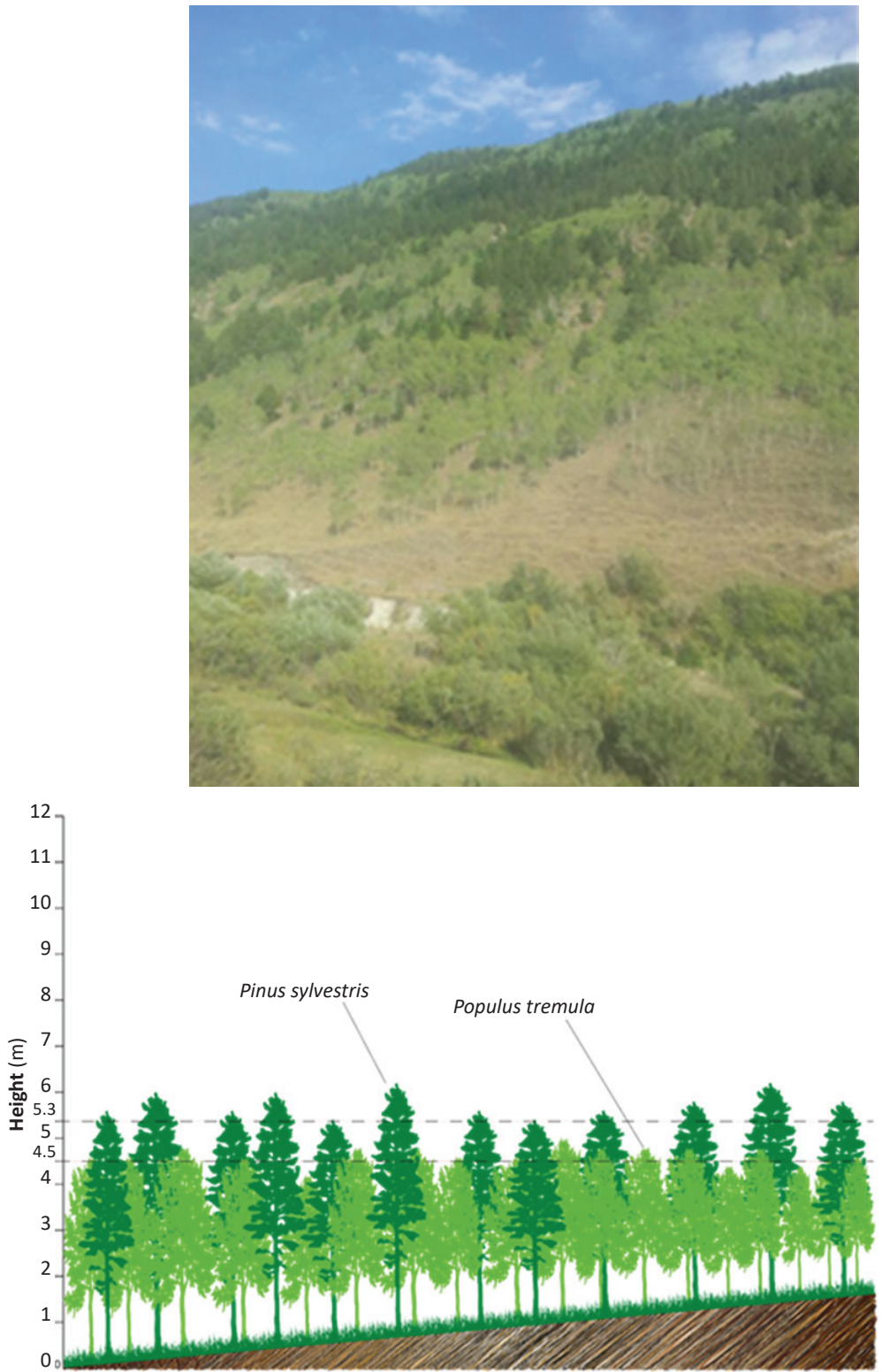

Altitude $(m)=2460$

Canopy $=0.8$

Density $=0.7$

Aspect $=\mathrm{N}$

\section{Populus tremula}

Mean Height $(\mathrm{m})=4.5$

Mean Diameter $(\mathrm{cm})=6.7$

Pinus sylvestris

Mean Height $(\mathrm{m})=5.3$

Mean Diameter $(\mathrm{cm})=9.2$

FIGURE 6. Profile of Populus tremula and Pinus sylvestris stands at fourth altitude level (2,460 m.a.s.I.). 
This shows that a new marginal natural population related to aspen trees has been detected in Pasinler in the Erzurum province, which at the same time indicates that the upper limit value in the vertical natural distribution of these species should be updated. In this context, an important contribution has been made to updating the researchbased information concerning aspen trees $[23,24]$, which is an important forest tree species in Turkey, and which has important features such as fast growth and strong root shoots, as well as being one of the pioneer species.

\section{CONCLUSIONS}

As a result of this study, a new natural distribution area of aspen, one that was not mentioned in previous and recent research in Turkey, has been discovered in the area between Timarlı Valley and Timan Plateau in Pasinler in the Erzurum province. Furthermore, the upper limit of the altitude, where this specific species of aspen could thrive, was updated to $2,460 \mathrm{~ms}$. Considering the insufficient forest percentage in the region, the extreme climate and conditions of the habitat and landslide, erosion and avalanche risks that may arise therefrom, the use $P$. tremula is of utmost importance for the protection of residential and agricultural areas in the region, and for ensuring the conservation and continuity of aspen trees. In this context, it can be seen that $P$. tremula, which has a wide geographic variation, is a very robust species of aspen that can thrive in arid areas as well as wetlands. The widespread use of aspen trees in afforestation endeavours in habitats with extremities, mainly semi-arid, arid and steppe areas, will be beneficial for the reproduction of new forests across Turkey. Although they are not as resilient against the early/ late frosts as birch (Betula spp.) and Scots pine trees, aspen trees have shown extraordinary resilience against frost in areas with extreme winter conditions, such as at the sample site. Aspen, which as a pioneer tree plays a vital role in the rebuilding or restoring the ecological balance in forests that have over time become degraded because of excessive cutting of trees and erroneous silvicultural interventions, should be used in the reclamation of broadleaved and mixed forests in a planned manner. In areas where forest degradation has taken place due to fires, snows and storms, aspen trees, due to of their fast growth and strong root shoots, should be used to restore the forest structure that has been damaged. In addition, genetic resources that represent marginal and peripheral populations, both within and outside the natural distribution area, should be established and protected.

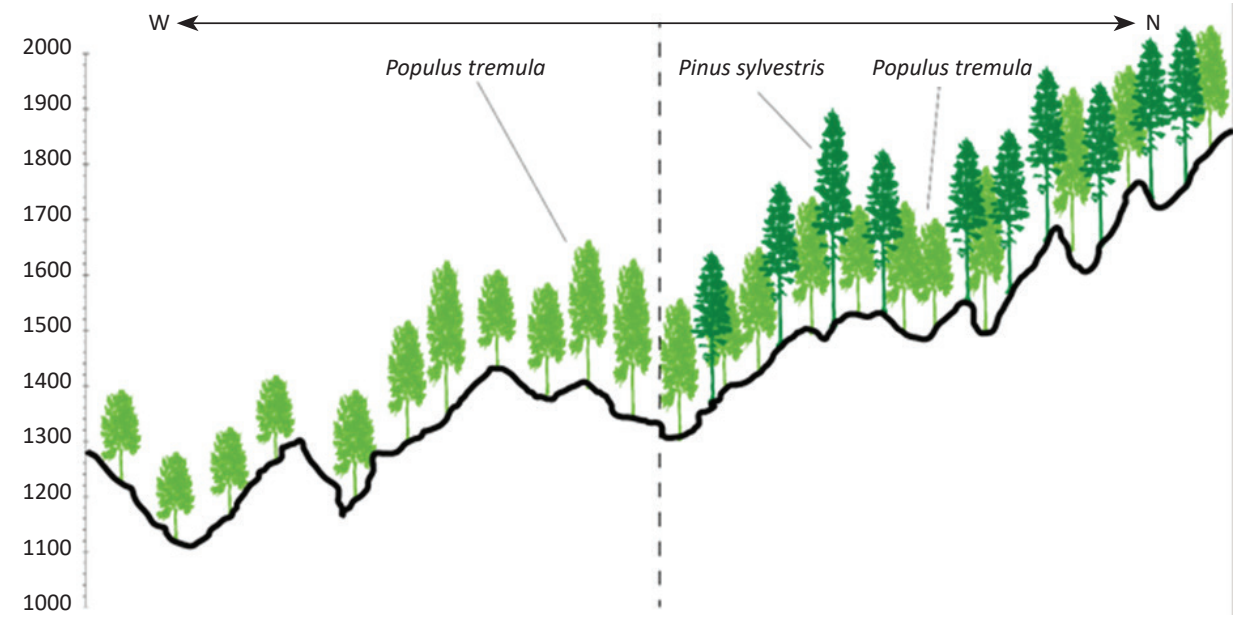

FIGURE 7. Cross-section of pure and mixed stands of aspen along the altitude levels (whole area).

\section{REFERENCES}

1. FAO 2018 The State of the World's Forests. Food and Agriculture Organization of the United Nations, Rome, Italy, $139 \mathrm{p}$

2. ÜRGENÇ S 1982 Forest Tree Breeding. University of İstanbul, Faculty of Forestry, No: 2836/293, İstanbul University Publisher, İstanbul, Turkey, $414 \mathrm{p}$

3. TUNÇTANER K 2007 Forest Genetic and Forest Tree Breeding. Turkish Forester Association, No: 4, Turkish Forester Association Publisher, Turkey, $364 \mathrm{p}$
4. YALTIRIK F 1993 Angiospermae. University of İstanbul, Faculty of Forestry, No: 3767/420, İstanbul University Publisher İstanbul, ìstanbul, Turkey, pp 46-51

5. TUNÇTANER K 2008 Genetic Improvement and Selection of Poplars. Directorate of Research on Poplar and Fast Growing Forest Tree Species, No: 19, Directorate of Research on Poplar and Fast Growing Forest Tree Species Publisher, Izmit, Turkey, $268 \mathrm{p}$ 
6. SAATÇIOĞLU F 1969 Basic Principles of Silviculture. University of İstanbul, Faculty of Forestry, No: 1429/138, İstanbul University Publisher, İstanbul, Turkey, $323 p$

7. ÖNER N, ASLAN S 2002 Technological Properties and Possible Uses of Trembling Poplar (Populus tremula L.) Wood. Süleyman Demirel Üniversitesi Orman Fakültesi Dergisi A (1): 135-146

8. KELES H 2016 An Evaluation Natural Trembling Poplar (Populus tremula L.) Forests in Erciyes Mountain (KayseriTurkey). Erciyes University Journal of Natural and Applied Sciences 32 (3): 1-14

9. CAUDULLO G, DE RIGO D 2016 Populus tremula in Europe: distribution, habitat, usage and threats. In: San-MiguelAyanz J, de Rigo D, Caudullo G, Houston Durrant T, Mauri A (eds) European Atlas of Forest Tree Species. Publ. Off. EU, Luxembourg, pp e01f148

10. GDM 2017 Meteorological Data of Pasinler District (19672017). General Directorate of Meteorology Publisher, Ankara, Turkey, $12 \mathrm{p}$

11. BARIK K 2011 Effects of Barnyard Manure and Beet Pulp Addition on Some Soil Properties. Atatürk University. Journal of Agricultural Faculty of Atatürk University 42 (2): 133-138

12. BAYBURTLU \$̧ 2007 Contraction of Stem Volume Tables and Site Index Tables for Trembling Aspen. MSc Thesis, University of Karadeniz Technical, Faculty of Forestry, Trabzon, Turkey, $53 \mathrm{p}$

13. PEHLIVAN S 2010 Construction of Tree Volume Tables of Scots Pine (Pinus sylvestris L.). MSc Thesis, University of Karadeniz Technical, Faculty of Forestry, Trabzon, Turkey, $63 \mathrm{p}$

14. MYKING T, B $\varnothing$ HLER F, AUSTRHEIM G, SOLBERG EJ 2011 Life History Strategies of Aspen (Populus tremula L.) and Browsing Effects: A Literature Review. Forestry 84 (1): 61-71. DOI: https://doi.org/10.1093/forestry/cpq044
15. SHOROHOVA E, KUULUVAINEN T, KANGUR A, JÖGISTE K 2009 Natural Stand Structures, Disturbance Regimes and Successional Dynamics in the Eurasian Boreal Forests: A Review with Special Reference to Russian Studies. Ann For Sci 66 (2): 201-220. DOI: https://doi.org/10.1051/ forest $/ 2008083$

16. ROBALTE L, MATISONS R, ELFERTS D, BRÜMELIS G 2012 Natural Structures and Disturbances in an Old Growth Wet Norway Spruce Forest in The Nature Reserve Gruzdovas Mezi, Latvia. Environmental and Experimental Biology 10: 81-87

17. BØRSET O 1956 Silviculture of Aspen. Scottish For 14: 68-80

18. PETERSON EB, PETERSON NM 1992 Ecology, Management and Use of Aspen and Balsam Poplar in the Prairie Provinces. Forestry Canada Northwest Region Special Report 1, British Columbia, Canada, $252 \mathrm{p}$

19. SHEPPERD WD, ROGERS PC, BURTON D, BARTOS D 2006 Ecology, Biodiversity, Management, and Restoration of Aspen in The Sierra Nevada. United States Department of Agriculture (USDA) Forest Service, Rocky Mountain Research Station General Technical Report RMRS-GTR-178, Fort Collins, USA,124 p

20. ANONYMOUS 1994 Poplar Cultivation in Turkey, Directorate of Research on Poplar and Fast Growing Forest Tree Species Publisher, İzmit, Turkey, $268 \mathrm{p}$

21. BOKALO M, COMEAU PG, TITUS SJ 2007 Early Development of Tended Mixtures of Aspen and Spruce in Western Canadian Boreal Forests. Forest Ecol Manag 242 (2-3): 175-184. DOI: https://doi.org/10.1016/i.foreco.2007.01.038

22. TOPLU F, TUNÇTANER K, TULUKÇU M 1991 Investigation on Propagation with Cutting of Trembling Aspen. Directorate of Research on Poplar and Fast Growing Forest Tree Species Publisher, No: 154, İzmit, Turkey, $16 \mathrm{p}$

23. ÜÇLER AÖ 1994 Propagation with Tissue Culture Techniques of Trembling Aspen (Populus tremula L.) and Caucasian Lime (Tilia rubra DC.). PhD Thesis, University of Karadeniz Technical, Faculty of Forestry, Trabzon, Turkey, $113 p$

24. BIRLER AS 2010 Propagation of Poplar in Turkey. Directorate of Research on Poplar and Fast Growing Forest Tree Species. Publisher, No: 22, Izmit, Turkey, $224 \mathrm{p}$ 
